\title{
SOCIOCULTURAL ADJUSTMENT AND COPING STRATEGIES OF KOREAN AND JAPANESE STUDENTS IN A THAI INTERNATIONAL COLLEGE
}

\author{
Douglas Rhein* \\ Mahidol University International College, 999 Bhuddamonthon 4 Rd. Salaya, \\ Nakhon Pathom, 73170 Thailand \\ dougrhein@hotmail.com
}

Published online: 15 January 2018

To cite this article: Rhein, D. 2018. Sociocultural adjustment and coping strategies of Korean and Japanese students in a Thai international college. International Journal of Asia Pacific Studies 14 (1): 57-78, https://doi.org/10.21315/ijaps2018.14.1.3

To link to this article: https://doi.org/10.21315/ijaps2018.14.1.3

\begin{abstract}
This study is devoted to understanding the adjustment issues Japanese and Korean international students face in Thai international higher education. An exploratory study of 15 visiting Korean college students and 15 visiting Japanese college students in Thai international programs was conducted using qualitative methods. A series of 30 face-to-face in-depth interviews regarding the participants' sociocultural adjustment to their host community was conducted in 2015-2016. Participants responded to open-ended questions regarding their adjustment experiences and perceptions of the host culture. The interview data was thematically coded into several categories. Participants' experiences were diverse and ranged from very subtle forms of discrimination and stereotyping to sexual harassment. The most frequently reported impediments to sociocultural adjustment included Thai language issues, excessive undesirable attention from the host community, academic adjustment, and difficulty establishing friendships with the host nationals. The most commonly reported coping strategies reported were the use of social support networks and social isolation from the host community. Implications for international relations departments and international programs within a Thai context are discussed.
\end{abstract}

Keywords: International education, Thailand, higher education, culture, ethnicity

(C) Penerbit Universiti Sains Malaysia, 2018. This work is licensed under the terms of the Creative Commons Attribution (CC BY)(http://creativecommons.org/licenses/by/4.0/). 


\section{INTRODUCTION}

As a result of the recent growth in globalisation and the internationalisation of higher education, cross border student mobility has increased dramatically (Altbach and Knight 2007). Therefore, international higher education campuses and classrooms are rapidly becoming more ethnically diverse (Bass and Bass 2008) and researchers are taking notice. International students have become the focus of growing interest among educational researchers (Seeber et al. 2016). However, this was not always the case. Historically, the importance of the youth and student market was largely ignored because of the assumption of its low market value. However, the modern sentiment favours youth and student travellers with more research into students' habits (Richards and Wilson 2003). The first World Tourism Organisation conference on youth tourism, which took place in November 1991, was one of the first to internationally emphasise this market segment (Richards and Wilson 2003). Additionally, the World Youth Student and Education (WYSE) Travel Confederation was established in 2006 when the International Student Travel Confederation and the Federation of International Youth Travel Organizations (FIYTO) joined forces. The development of global organisations supporting the growth of the youth and student market exhibits the significance of the segment (WYSE 2006). More recently, as a result of changes in the global economy, many university students seek overseas study possibilities in hopes of improving their opportunities, skills and capabilities (Yusoff 2011).

For many years Thai higher education has been attempting to increase the number of international students (Rujiprak 2016). As the number of international students in Thailand has increased, this has led to Thailand becoming a regional international education hub (Cochrane 2014). In 2009, almost 3.7 million tertiary students enrolled outside their country of citizenship, representing an increase of more than 6 percent on the previous year (OHEC 2011). South Korean student enrolment in international programs in Thai higher education increased over 30 percent from 340 students to 493 students between 2008 and 2012; whereas Japanese student enrolment decreased by 9 percent from 403 in 2008 to 369 in 2012 (OHEC 2012). The increasing numbers of students studying outside of their home country (Rizvi 2011) has led to a growing expectation that many higher education institutions, whether in Western nations or in Southeast Asia, will continue to have a rising number and proportion of inbound international students. That said, there is a distinct lack of information available regarding the sociocultural adjustment 
demands experienced by Asian students studying within other Asian international programs.

International student relevance to higher education is increasing due to their ability to contribute economically through often exorbitant tuitions rates at many schools, their ability to enrich the cultural diversity of the classroom and campus, and their ability to assist in the development of intercultural competence for all involved. However, many international students struggle with their pursuit of an international degree (Ozturgut and Murphy 2009). The majority of research involving Asian international students is conducted in Western nations. However, given the rapid expansion of internationalisation in Thai higher education, it has become important to gain further insight into the adjustment demands faced by various groups of students enrolling in Thai international programs. Therefore, this article intends to fill the gap in available literature through the articulation of an exploratory analysis of Korean and Japanese international student sociocultural adjustment to Thai international programs. This analysis begins with a description of international education in Thailand and discusses the adjustment demands Korean and Japanese international students encounter. The final section examines the specific comments of 15 Korean students' and 15 Japanese students who reported on their experiences while studying in international college programs in Thailand.

\section{DIMENSIONS OF ADJUSTMENT}

Defining important terms such as "adjustment" has proven difficult although adaptation, acculturation and adjustment have all been used to describe the same process (Ward and Searle 1991). Ward (1996) argued that adjustment is best understood in terms of stress and coping frameworks while adaptation is best understood within the framework of socials skills and culture learning. Adjustment is a complex process of overcoming obstacles, responding to the host culture and problem solving. While sociocultural adaptation typically follows a standardised learning curve (Ward and Kennedy 1999), there is limited consensus on the stages of adjustment and there is yet no clear model of cultural adjustment. Early works (Lysgaard 1955; Oberg 1960) describe a U-shaped curve model of adjustment featuring four stages, honeymoon, crisis, recovery and adjustment. Researchers such as Gullahorn and Gullahorn (1963) proposed a W-curve model which includes the final stage when travellers return home and Brown (1980) followed the multi-stage theory of adjustment. Adler (1975) also suggested a five-stage process: contact, 
disintegration, reintegration, autonomy and independence. Further work by Torbiorn (1994); Mohamed (1997), continue to explore adjustment as a series of stages. In 2007, Townsend and Wan supported the U-curve model. However, more recent research (Brown and Holloway 2008) implemented ethnographic research models and found that the U-curve model of adjustment was not followed by the sample, instead negative psychological factors were seen to be more influential and emphasis was placed on nervousness, anxiety, stress, uncertainty, feeling adrift and weather at the beginning of their stay.

An alternative to the curve or sequential models of adjustment is exemplified by the research of Berry and associates (Berry et al. 1989) who proposed the concept of psychological acculturation as two dimensional; maintenance of original culture and maintenance of relationships with new groups and further divided these dimensional responses and identified four acculturative strategies: integration, separation, assimilation, and marginalisation. This conceptualisation of adjustment allowed individuals multiple cultural affiliations with the host culture without necessarily limiting or reducing any identification with their culture of origin (Swagler and Jome 2005). A criticism of Berry's work is that it does not go far enough to explain the variations of acculturative impact in regard to differences in ethnicity, context and individual variables on participants within his model. It is these individual differences which make adjustment a subjective phenomenon. This led to further exploration of social identity theory which explored individual perception of self and personal identity (Tajfel and Turner 1979; Phinney 1990) in comparison to host nation attitudes of self and personal identity. Following the research of Berry and associates, Searle and Ward's research began to explore those travellers who voluntarily visited new cultures and investigated the elements of culture shock (Searle and Ward 1990). They argued that sociocultural adjustment is the natural outcome of acculturation; while psychological adjustment is far more complicated as there are many variables which influence an individuals' adjustment, whereas sociocultural adjustment can be measured in terms of how individuals perform in daily tasks in a new culture. The subjective nature of adjustment is an essential area of inquiry as the relationship between individual psychology and the host culture will have an impact on the adjustment process. The work of Bhatia (2011) has called on the use of narrative psychology to understand the process of adjustment through the analysis of the subjective self and an individuals' sense of identity construction to understand how one conceptualises the experiences of cross cultural transition. 


\section{SOCIOCULTURAL ADJUSTMENT}

Sociocultural adjustment is often viewed as the degree of comfort and familiarity an individual has within the host culture (Black 1988). Sociocultural adjustment can be broadly classified into two categories; intrinsic factors such as individual characteristics and external factors such as the degree of difference in the new environment or organisation. There is a large body of work which has examined the factors associated with international student adjustment (Brisset et al. 2010; Chirkov et al. 2008). Fritz et al. (2008) analysed different groups of international students in North America and addressed which stressors affected each group as well as the linguistic and financial influences on the groups. Ward (2004) explored the importance of host language skills and "the quality and quantity of intercultural interactions" (190). As with many other research examples, Asians reported more problems with language whereas Europeans experienced more problems in regard to homesickness. Further studies by Pantelidou and Craig (2006) concluded that social support is highly correlated with adjustment as is gender. An analysis of international student retention reveals that men are more likely to experience sociocultural adjustment, as are the extroverted (Fritz et al. 2008; Pantelidou and Craig 2006). Rosenthal et al. (2007) claimed that adjustment was influenced by many factors not related to country of origin such as self-esteem, age, gender (women scored higher in shock and distress compared to men) and previous international exposure. The results of Wang (2009) also demonstrated that female international students experienced more difficulty adapting than men and displayed less resilience than the male participants. Previous research on sociocultural adjustment emphasized the positive influence of socialising with host nationals (Swami et al., 2010); however, there is also evidence that this socialisation can be distressing and may impact academic achievement (Greenland and Brown 2005). Research using qualitative methods explored adjustment issues related to loneliness (Sawir et al. 2008), discrimination (Poyrazli and Garhame 2007), feelings of alienation (Major 2005) emotional adjustment problems (Ang and Liamputtong 2008), academic setting (Townsend and Poh 2008) and language (Trice 2003). Several studies indicated that social support (Chirkov et al. 2008; Jung et al. 2007; Lee et al. 2004; Sumer et al. 2008; Toyokawa and Toyokawa 2002) and self-efficacy (e.g., Li and Gasser 2005) are crucial factors in international students' adjustment. Previous studies have also confirmed many international university students are not satisfied with their multicultural relationships (Choi 1997) and expressed the need for local assistance with sociocultural adjustment (Nesdale and Todd 1997). These studies were done 
in Australia, Europe, the United States and Canada. Regrettably, less attention has been paid to these issues in Thailand.

\section{JAPANESE AND KOREAN CULTURAL INFLUENCES IN THAILAND}

Korea and Japan share some cultural similarities with Thailand such as collectivism, an interdependent self-construal, conflict avoidance, high power distance, and elements of Confucianism (Kim 2001). While there is a tendency to approach these student samples from a cultural proximity perspective, there are distinct differences between these cultures and other Asian nation's cultures. Although the Japanese invasion and subsequent occupation of Korea from 1910-1945 did result in great political and social conflict, much of the shared history of these nations is just as unknown to the Thais as the Thai participation in the Korean War in the early 1950s. However, this article does not set out to detail the distinctions in national culture among these nations. The purpose of this inquiry is to determine what, if any, differences exist among the adjustment issues encountered among Japanese and Korean international students.

A particularly interesting phenomenon to explore within this context is the impact of the "Korean Wave" and the resulting perceptions of Koreans while in a Thai community. "Hallyu," or the Korean wave, began in China in the late 1990s (Jang 2012) with a long list of Korean television series, movies, songs and various other Korean media which shifted the Thai public attention from American and Japanese media which was prevailing to Korean media (Visser 2002). Prior to this, Japanese media, particularly manga and anime, largely dominated the Thai market (Tidarat 2002). This wave of Korean programs quickly began to dictate television airtime in Taiwan, Singapore, Vietnam, Indonesia and Thailand throughout the late 1990s and early 2000s due to the higher quality and lower costs when compared to Hollywood and Tokyo. By the early 2000s, K-pop outsold J-pop. The Korean film and music stars quickly became household names in Asia and began to influence fashion, cosmetics, and cosmetic surgery spending (Kim 2009). Popular Japanese video games were quickly replaced with the Korean game Ragnarok in 2001 (Thamdee 2007) and the intensity of all things Korean was further buttressed by the co-hosting of the World Cup in 2002. In 2005 a television series entitled Dae Jang Geum arrived in Thailand and was an immediate hit. Thailand's Channel 5 television reported a 184 percent profit increase following the release of the Korean drama (Amnatcharoenrit 2006). It was at this time that Chulalongkorn 
University, the oldest and most prestigious university in Thailand, began a Korean language program for their students. Since then the Korean wave has only grown.

In 2012 the Korean musician Psy released "Gangnam Style" which became the first YouTube video to reach 1 billion views. Both the song and the dance movements associated with the video were imitated by many Asian political leaders and have influenced global pop culture. While both Japanese and Korean media have a history of popularity in Thailand, current trends favour the modelling of all things Korean. The Korean wave changed the Thai perceptions of Korea and led to a boom of Korean fashion outlets, restaurants, language schools, cosmetics and all Korean products.

Much of the literature available on Japanese and Korean international student adjustment has been conducted on international students who enter Western English speaking academic settings such as Australia, England or the United States. Additionally, there is a smaller body of research which focuses on Asian international students relocating to an Asian academic setting. As such it is important to identify the sociocultural adjustment issues these students face in Thai international higher education programs.

\section{METHODOLOGY}

A qualitative case study design was chosen to elucidate the details of the participants' experiences in Thailand. The questionnaire in this study was adapted from Ward and Kennedy's Sociocultural Adaptation Scale (SCAS) (Ward and Kennedy 1999). Due to the limited sample size involved in the study (30 participants), the original 29 SCAS item list with a five-point Likert response scale was customised into a qualitative study by transforming each item into an open question form. This adaptation allowed for the development of a semi-structured open-ended interview with each participant. The initial questions were framed in an open-ended non-directive style to establish rapport with the participants. Particlar emphasis was placed on the challenges the particpants discussed through more probing inquiry. All participants were asked about their experiences and reponses to their new milieu. One on one semi-structured interviews were conducted in English with the particpants. English is the language of instruction and assessment at international programs in Thailand and all international students are requiered to pass either TOEFL or IELTS prior to admission. The inteviews lasted approximately 30-45 minutes. 


\section{PARTICPANT SELECTION}

Participants who were eligible for interviews met two criteria: (1) are Korean/ Japanese nationals studying at Thai international colleges; and (2) do not speak Thai. Fifteen Korean and 15 Japanese international students volunteered after being contacted by the researcher at the international student orientation seminar at the beginning of each academic semester. Following participants' contact with the researcher, all were informed of the purpose, scope and the time commitment required of them. Participation in the study was purely voluntary. All participants were reminded of their right to withdraw from the study at any time. One week after each interview, the participants were given a transcript and the option to remove, edit or add to their comments. This purposive selection process ensured both convenience and representativeness (Linclon and Guba 1985). All of the applicants were visiting students aged 18-23 years old studying in social sciences and business courses in Thai international programs.

\section{DATA ANALYSIS AND INTERPRETATION}

Thematic identification and coding provided a rich description of the naturalistic data. As standard practice, each interview was audio recorded on then transcribed (Erlandson et al. 1993). Each interview transcript was read multiple times and the initial analytical notes were made in the left margin of each page. The right margin was used to idenitfy emerging themes and key concepts or phrases which captured the spirit of the adjustment experience. Specific attention was given to common or overlapping themes. This thematic data analysis was intended to identify frequency, specificity and emotionality of participant responses (Krueger and Casey 2009). As more themes evolved it became necessary to combine major themes with subordinate themes. All of the themes for each interview were compared to the transcripts from other interviews to create a consolidated master theme group.

\section{RESULTS}

There was agreement among most participants that adjustment to Thailand was not as difficult as they had originally expected. Participants also agreed that some adjusment issues were inevitably problematic such as weather conditions. However, four common themes related to adjustment demands 
emerged from participants: i) language issues, ii) academics iii) social issues, and iv) making friends. In the section below, each of these issues is discussed with direct quotes from the participants.

\section{LANGUAGE ISSUES}

It is important to note that Thailand is a unique environment for international students. Most students arrive from overseas as non-Thai speakers as well as being non-native English speakers. This means that most international students speak at least three languages a day (i.e., their mother tongue (Korean or Japanese), English while in class and Thai while in society). This adjustment demand was the most common issue among participants. While the Korean and Japanese students arrived with the necessary level of English, they had little to no understanding of the Thai language which often created a barrier in social situations. As the majority of the student population is Thai, the Thai language is most commonly used outside of the classroom. During other on campus activities such as clubs, sports and eating Thai is the most common language heard on and off campus.

A third-year male Korean student commented:

Honestly, if you are not a Thai, it is really difficult to join any groups. Even in school where clubs are compulsory, it's hard for foreigners to fit in because the majority of the students are Thai and they're speaking only in Thai. They know we are weak in speaking and listening in Thai but they keep speaking in Thai. I have tried going to clubs but I stopped because they all spoke in Thai. I still don't understand why they invite the foreign students and then do everything in Thai. Why do they ask us to join and then speak in a language we can't understand?

A second-year female Japanese student further remarked:

Yes, language is a big problem for me. I have to switch to English at school, Thai in the canteen and then I get home and I can relax and go back to Japanese. It's confusing and tiring.

The issue of Thai language was perhaps most problematic when used in the classroom. This was a frequent source of frustration among the participants. For example, one Korean student expressed his disappointment: 
If you ask if I'm happy with my life in Thailand and living away from home, I would probably say yes, but I don't think I am pleased with my life in university and having to take classes with Thai students. I am not saying I don't like them, but I feel uncomfortable working in classes with Thais. Even the teachers are Thais and some lecturers speak a lot of Thai in class, often asking and answering questions in Thai.

While in the classroom English is supposed to be the lingua prima in international programs, once the students leave the classroom Thai becomes the language of survival. This is particularly problematic for day to day purchases and excursions. For example, one third year male Korean student stated the following:

The security guards, accounting and other university staff in the international relations department cannot speak English or Korean so when I need help or if I get lost on campus it takes hours to find my way back. The signs are in Thai, the menus are in Thai and even the taxi drivers really only understand Thai. So, I'm learning Thai now so I can survive.

Many of the respondents' comments on the difficulty of language in the Thai setting were similar as previously reported in Trice (2003) as well as the resulting feelings of alienation (Major 2005). The lack of participation in clubs with host nationals limits opportunities for the development of social support (Toyokawa and Toyokawa 2002). Therefore, participants chose to cope with this aspect of linguistic isolation through the development of relationships with other international students who either spoke their native language or conversed in English.

\section{ACADEMICS}

Participants were asked to reflect on the impact of the university environment and how the classrooms or academic situation influenced their overall sociocultural adjustment.

One Korean student summarised the most common response among the participants: 
Even though this is an international college, it feels Thai. It has a lot of Thai influence, like the uniform and the culture and the teachers. I thought it would be less Thai and more international or Western. It's not bad but it takes a while to adjust to.

Many of the respondents commented on the similarity of academic cultures and the need to show deference to the teachers. This cultural similarity (Swami et al. 2010) may have acted as a buffer from some of the stressors which impact participants from Western nations who are not as familiar with Confucian principles and appropriate classroom etiquette from the Thai perspective. International higher education in Thailand is different than programs in Western nations. The Thai system includes mandatory uniforms, class attendance, participation in clubs and other activities. Many students do not ask questions as a sign of respect for their teachers and public disagreement is strongly discouraged. A Korean student made the following observation:

The education system in Thailand is very similar with Korea's education system. Both countries' education is based on memorising what is in the textbook instead of discussion or activities. This makes it easy for Korean students to focus on their studies in Thailand. Korean students also easily understand the hierarchy between teachers and students and older students and younger students. I can socialise with the other Korean exchange students more because I don't have to worry about school.

The course load and requirements were not considered a stressor among the students interviewed but many commented on their discomfort with academic group work. A Japanese student complained:

We are all part of a group project but not everyone is working the same. Sometimes I think they are taking advantage but I can't say anything and in the end we all get one grade even though someone did nothing. It's not fair but we have to accept this. In Japan we don't do it like this.

\section{SOCIAL ISSUES}

Since the Korean wave hit Thailand in early 2000s, Korean media has been very popular (Ubonrat and Shin 2007). This has influenced the experience of Korean international students in Thailand. Many of the female respondents 
commented on feelings of discrimination as discussed in Poyrazi and Garhame (2007). The Korean wave clearly had an impact on the host nationals' treatment of the visiting Korean students, particularly the female students. A fourth-year Korean female student expressed her disappointment when she said:

It is an everyday life of experiencing staring, stalking, being called "Korean" and being looked at as a Korean, not a friend. The biggest issue is when I am eating or doing a presentation and someone takes my picture. I know it's going into social media and it's going to be a gossip. I really don't like that students here gossip about Koreans so much. I'm not famous, why are they taking my picture?

Many respondents commented on the status of Koreans in Thailand today. For example, a Korean female student commented:

People just see me and know I'm Korean so they want to be friends with me. Maybe they think they will have higher status if they hang out with Koreans, I don't know but it doesn't feel genuine. Basically, the only reason they want to be seen with me is I look Korean. It's obvious and pretty shallow.

Many of the female Korean respondents complained of excessive attention from the host nationals. This was particularly distressing when the host nationals took photographs with their cell phones and created chat rooms to discuss the visiting students' appearance. While many of the participants explained that they thought this was due to the Korean wave, it was no less distressing. One student illustrated this potentially humiliating experience:

Once, I was working in a group of five. My group members were at the library first. When I got there, I saw two girls looking at my photo on their phones and talking about it. When they saw me they were shocked but pretended they were doing something else. I later heard that someone set up a chat room about me and my friends. There were many situations like this.

Another Korean female student made a similar observation:

As a Korean woman, I get a lot of unwanted attention. I think it's because I have white skin and Korean fashion. I'm usually fine on campus but most Korean women don't walk around off campus or, if we need to, then we hang out in packs and try to do our grocery shopping together and come back together. It feels safer in groups. 
The Koreans in this study chose to travel in groups as a coping mechanism to avoid the unwanted attention. The Korean participants did not report a sense of danger or possible violence, their avoidance of host nationals was based on an avoidance of social bullying and a need for a sense of emotional security. On the other hand, the Japanese perception of socialising with the host culture was equally problematic but for different reasons. The primary concerns regarding socialisation reported by the female Japanese students was safety and other issues related to vigilance. A female Japanese student said:

Maybe because I've heard many stories about crime especially sexual crimes in Thailand, from my university in Japan, the office staff had an orientation for the students coming to S. Asian countries, about those crimes and how to be careful. They told us to take care of ourselves because it's very dangerous here. I don't want to think badly about Thais but I feel I have to be aware all the time.

Similar to the Korean females reports of safety issues off campus, the Japanese females also commented on regularly being stared at and receiving unwanted attention from local men. One Japanese female commented:

There are many places where I feel uncomfortable. At school, it's fine but not off campus. I feel much safer in Japan. I feel very safe inside the university but once I go out it's kind of shady and if I walk alone or take a taxi alone I feel very uncomfortable and sometimes in markets I grab my bag in front of me so nobody can steal it. It's not everywhere but I'm always cautious when I go off campus.

The issues regarding the safety of socialising off campus were a concern only to the female respondents which supports previous research regarding the gender and sociocultural adjustment (Fritz et al. 2008; Pantelidou and Craig 2006). Female participants consistently reported more distress than the men, particularly regarding the intensity of unwanted attention they received. Both the Japanese and the Korean men said they felt comfortable walking at night and did not worry about crime in Thailand. Additionally, during the interviews many of the Japanese and Korean men made a similar observation regarding the potential dangers for women going out alone or those who are not accompanied by their male counterparts. 


\section{FRIENDSHIP}

Many of the participants discussed the lack of genuine friendships with host nationals. The respondents often said that they spent much more time with international students than locals. The Japanese formed their own group and the Korean formed their own group and both groups had limited friendships with the host community. When asked to explain, both the Koreans and the Japanese commented that the Thais act much differently in class and outside of class. Many of the respondents said that while the Thais were very polite and conservative in class, as soon as they left campus their behaviour changed dramatically. One male Japanese student commented:

In class they're quiet but it's kind of interesting to see them acting really differently because they spend so much time on social media. They always take pictures of themselves. When I go out with Thai students, they spend hours just taking photos or looking at Facebook. They take a hundred pictures of themselves and then share it. I sometimes feel bored because they just keep taking pictures of themselves but I know they have another side too, so I want to see that side, not the selfie side.

A Korean woman shared her opinions on developing relationships with the host nationals as:

It's difficult to have a true friendship here. Many people just want Korean friends but then when we hang out everything is in Thai and all they do is take selfies with me and post it on Facebook. I feel like I'm being used, so I just hang out with the other Koreans or the international students. It's shallow and I think people are trying to promote themselves in a fake way. I think I have to accept that it's a selfie culture.

\section{DISCUSSION}

Administrators and faculty hope that the influx of international students results in the addition of varying perspectives and ethos which enhance classroom experiences, allow for the development of a more intercultural understanding of and appreciation for diversity and the ability to embrace people from all over the world. The participants in this study did contribute to the academic prestige, financial revenue and cultural exchange for the host universities involved. Both the Korean and Japanese international students in this study 
had generally positive comments about their experiences in Thai international programs. Many students said they would recommend this to friends and would look back with fond memories regarding their experiences here.

The first and most prominent adjustment barrier which emerged was language. International colleges in Thailand utilise English as the language of the assessment, admissions and classroom discussions. This study revealed that both Korean and Japanese students are often in situations where Thai became the language of communication during activities and this placed these students at a disadvantage socially. The use of Thai language as a fundamental element of adjustment is an issue for administrative bodies as marketing Thai international programs and events based on the use of English can be viewed as problematic and perhaps disingenuous. It has been argued (Swagler and Ellis 2003) that a failure to understand language often means there is a failure to understand the culture as well. Previous research on the importance of host language ability involving Japanese and Korean participants conducted in the United States reached similar conclusions (Cox and Yamaguchi 2010; Huang and Rinaldo 2009; Lee and Carrasquillo 2006). This may indeed be the case of Korean and Japanese students in Thailand and their comments regarding the selfie culture. Perhaps if the visiting students had more Thai language skills and could socialise with the hosts more comfortably, then there would have been more conversations and less selfies and social media focused experiences for all involved.

The academic aspect of studying in Thai international programs was not particularly distressing as most participants agreed that adjustment was generally smooth with a few minor exceptions such as the uniform policy. The similarity in scholastic culture and background made academic adjustment fairly easy for the students with the other exception of group projects. Within this context, both groups of students complained of free riders and the lack of equitable participation among all members of the group. Most of the Korean and Japanese students chose to befriend others of the same nationality or other international students. This is not a positive aspect of the research as interacting with the host culture and participating in social events can have a positive impact of sociocultural adjustment (Searle and Ward 1990). Regarding social adjustment, one of the surprising issues which impacted the experiences of particularly Korean females in Thailand was the Korean Wave. Many of the respondents complained of discrimination, sexism, stereotyping and various other forms of prejudice. The findings in this study support previous research on the negative impact of discrimination (Poyrazli and Garhame 2007), social alienation (Major 2005) and the resulting emotional adjustment problems (Ang 
and Liamputtong 2008), as well as perceived prejudice. This theme emerged particularly strongly among female participants who engaged in social avoidance defense strategies and group travel precautions to prevent further unwanted attention. Previous research has concluded that social support is an important variable in regard to international adjustment (Baba and Hosoda 2014, Ward et al. 2001; Yusoff and Chelliah 2010). Therefore, if Korean and Japanese international students develop or receive more social support from the host community it is probable that they will experience improved sociocultural adjustment.

Previous work (Ataca and Berry 2002) found that humiliating events which can trigger psychological issues and have a negative impact sociocultural adjustment. As evidenced from this research, the Korean students' response was often to avoid interaction with the host nationals. Even when the stereotypes were positive, the Korean students felt it was depersonalising and socially alienating. Goldsmith and Baxter (1996) reported that gossip was the most common form of daily talk among college students. Gossip serves an important social function albeit sometimes harmful to the recipients. In this research, the Korean international students considered gossip as a form of indirect aggression. Previous studies (McAndrew 2008) have shown the negative impact of gossip. In contrast to previous research which posits that gossip can facilitate social interaction among international students and is related to sociocultural adjustment (Yeh and Inose 2003), this research found that gossip had a negative impact as it was perceived as discrimination and thus decreased social interaction between the host and the Korean students. In conclusion, while the participants did adjust to academic life in Thailand they did not adjust to their host culture well. Most respondents chose to avoid interaction with their hosts outside of the classroom and created an international bubble filled with English, Korean or Japanese and other international students to facilitate their overall adjustment and maintenance of in-group social support.

\section{CONCLUSION}

There has been a considerable increase in the number of international students in Asian programs. The increasing diversity of international students in Thailand classes is also a global phenomenon (Bass and Bas 2008; Hames 2007). Using qualitative methods, this study aimed to address the paucity of research regarding Asian international students in programs in Thailand. As noted earlier, the increase in students studying abroad (Rizvi 2011) has 
created the likelihood that many tertiary education institutions, particularly in Asia will experience a rising number and proportion of inbound international students. This is evidenced in the Thai Office of Higher Education (OHEC 2012) which stated that $S$. Korean student enrolment in international programs in Thai higher education increased over 30 percent between 2008 and 2012. This study of Korean and Japanese international students has, in a small but substantive manner, filled the gap in international educational adjustment within the Thai context. Further elucidation of the other visiting students' sociocultural adjustment based on nationality, ethnicity or other defining characteristics is critical to understanding and improving the quality of experiences students have when visiting Thailand. It is therefore important to address the ways in which tertiary institutions facilitate the transition of such students within the host institution. Research suggests that a number of ways that have been demonstrated can enhance the induction of international students in the host institution, such as improving the teaching strategies and quality of education, expanding the offering of specific courses and overall availability of programs, providing a greater ratio of international faculty and supporting staff, and enhancing international partnerships, but student and employee retention is also an integral component of this process (Stohl 2007; Ramachandra 2011). If international programs in Thailand wish to retain this important student's segment then more attention should be given to the factors which hinder their sociocultural adjustment.

\section{NOTES}

Douglas Rhein is the Social Science Division Chair at Mahidol University International College, Thailand. He was born in America and attended university in United States, Thailand, England and Australia majoring in psychology, communications and education. Douglas lectures in many areas of psychology at Mahidol University International College. He regularly works with the public and private sector conducting workshops throughout Asia. Areas of training include education, leadership, intercultural management and operations issues. 


\section{REFERENCES}

Adler, P. 1975. The transitional experience: An alternative view of cultural shock. Journal of Humanistic Psychology 15: 13-23, https://doi.org/10.1177/002216787501500403.

Altbach, P. and Knight, J. 2007. The internationalization of higher education: Motivations and realities. Journal of Studies in International Education 2: 290-305, https://doi. org/10.1177/1028315307303542.

Amnatcharoenrit, B. 2006. South Korean Series helps push Channel 3 profit up by 184 Percent. Bangkok Post, 12 May.

Ang, P. L. D. and Liamputtong, P. 2008. "Out of the circle": International students and the use of university counseling services. Australian Journal of Adult Learning 48: $108-130$.

Ashworth, P. 2003. The origins of qualitative psychology. London: Sage.

Ataca, B. and Berry, J. W. 2002. Psychological, socio-cultural, and marital adaptation of Turkish immigrants. International Journal of Psychology 37: 13-26, https://doi. org/10.1080/00207590143000135.

Baba, Y. and Hosoda, M. 2014. Home away from home: Better understanding of the role of social support in predicting cross cultural adjustment among international students. College Student Journal 48 (1): 1-15.

Bass, B. and Bass, R. 2008. The Bass handbook of leadership: Theory, research, and managerial applications, 4th ed. New York: The Free Press.

Berry, J. W. et al. 1989. Acculturation attitudes in plural societies. Applied Psychology: An International Review 38: 185-206, https://doi.org/10.1111/j.1464-0597.1989. tb01208.x.

Bhatia, S. 2011. Narrative inquiry as cultural psychology: Meaning-making in a contested global world. Narrative Inquiry 21 (2): 345-352, https://oi.org/10.1075/ ni.21.2.13bha.

Black, J. S. 1988. Work role transitions: A study of American expatriate managers in Japan. Journal of International Business Studies 19: 277-294, https://doi.org/10.1057/ palgrave.jibs.8490383.

Brisset, C. et al. 2010. Psychological and sociocultural adaptation of university students in France: The case of Vietnamese international students. International Journal of Intercultural Relations 34: 413-426, https://doi.org/10.1016/j.ijintrel.2010.02.009.

Brown, H. D. 1980. The optimal distance model of second language acquisition. TESOL Quarterly 14: 157-164, https://doi.org/10.2307/3586310.

Brown, L. and Holloway, I. 2008. The initial stage of the international sojourn: Excitement or culture shock? British Journal of Guidance \& Counselling 36: 33-49

Chirkov, V. I. et al. 2008. Further examining the role motivation to study abroad plays in the adaptation of international students in Canada. International Journal of Intercultural Relations 32: 427-440, https://doi.org/10.1016/j.ijintrel.2007.12.001.

Choi, M. 1997. Korean students in Australian universities: Intercultural issues. Higher Education Research and Development 16 (3): 263-282, https://doi. org/10.1080/0729436970160302.

Cochrane, S. 2014. Comparative study of socio cultural adaption of foreign students on international programmers in Thailand. Interdisciplinary Studies Journal 14 (2): $250-273$. 
Cox, K. and Yamaguchi, S. 2010. Japanese graduate nursing students' perceptions of the teaching performance of an intercultural teacher. Nursing Education Perspectives 31 (3): 156-159.

Erlandson, D. A. et al. 1993. Doing naturalistic inquiry. Newbury Park, CA: Sage.

Fritz, M., Chin, D. and DeMarinis, V. 2008. Stressors, anxiety, acculturation and adjustment among International and North American students. Journal of Intercultural Relations 32: 244-259, https://doi.org/10.1016/j.ijintrel.2008.01.001.

Goldsmith, D. J. and Baxter, L. A. 1996. Constituting relationships in talk: A taxonomy of speech events in social and personal relationships. Human Communication Research 23: 87-114, https://doi.org/10.1111/j.1468-2958.1996.tb00388.x.

Greenland, K. and Brown, R. 2005. Acculturation and contact in Japanese students studying in the United Kingdom. The Journal of Social Psychology 145 (4): 373-390, https:// doi.org/10.3200/SOCP.145.4.373-390.

Gullahorn, E. and Gullahorn, T. 1963. An extension of the U-Curve hypothesis. Journal of Social Issues 19: 33-47, https://doi.org/10.1111/j.1540-4560.1963.tb00447.x.

Hames, R. D. 2007. The five literacies of global leadership: What authentic leaders know and you need to find out. West Sussex, England: John Wiley and Sons.

Huang, J. and Rinaldo, V. 2009. Factors affecting Chinese graduate students' cross-cultural learning. International Journal of Applied Educational Studies 4 (1): 1-13.

Jang, H. J. 2012. The Korean Wave and its implications for the Korea-China relationship. Journal of International and Area Studies 19 (2): 97-113.

Jung, E., Hecht, M. L. and Wadsworth, B. C. 2007. The role of identity in international students psychological well-being in the United States: A model of depression level, identity gaps, discrimination and acculturation. International Journal of Intercultural Relations 31 (5): 605-624, https://doi.org/10.1016/j.jintrel.2007. 04.001 .

Kim, Y. 2001. Becoming intercultural: An integrative theory of communication and crosscultural adaptation. Thousand Oaks, CA: Sage Publications.

Kim, C. 2009. Beauty industry could create the next Korean Wave. Chosun Ilbo. http:// english.chosun.com/site/data/html_dir/2009/10/15/2009101500909.html (accessed 30 May 2015).

Krueger, R. and Casey, M. 2000. Focus groups: A practical guide for applied research, 3rd ed. Thousand Oaks, CA: Sage Publications, https://doi.org/10.1037/10518-189.

Lee, K., S. and Carrasquillo, A. 2006. Korean college students in the United States: Perceptions of professors and students. College Student Journal 40 (2): 442-456.

Lee, J-S., Koeske, G. F. and Sales, E. 2004. Social support buffering of acculturative stress: A study of mental health symptoms among Korean international students. International Journal of Intercultural Relations 28: 399-414, https://doi. org/10.1016/j.ijintrel.2004.08.005.

Li, A. and Gasser, M. B. 2005. Predicting Asian international students' sociocultural adjustment: A test of two mediation models. International Journal of Intercultural Relations 29 (5): 561-576, https://doi.org/10.1016/j.ijintrel.2005.06.003.

Lincoln, Y. S. and Guba, E. G. 1985. Naturalistic inquiry. Beverly Hills, CA: Sage.

Lysgaard, S. 1955. Adjustment in a foreign society: Norwegian Fulbright grantees visiting the United States. International Social Science Bulletin 7: 45-51. 
Major, E. M. 2005. Co-national support, cultural therapy, and the adjustment of Asian students to an English-speaking university culture. International Education Journal 6 (1): 84-95.

McAndrew, F. T. 2008. Can gossip be good? Scientific American Mind Magazine, October/ November, 19, 26-30.

Mohamed, O. 1997. Counselling for excellence: Adjustment development of Southeast Asian students. In Overseas students in HE: Issues in teaching and learning, ed. McNamara, D. and Harris, R. London: Routledge.

Nesdale, D. and Todd, P. 1997. Promoting International Contact between Australian and International University Students. Journal of Higher Education Policy and Management 18 (1): 61-76.

Oberg, K. 1960. Culture shock: Adjustment to new cultural environments. Practical Anthropology 7: 177-182, https://doi.org/10.1177/009182966000700405.

Office of the Higher Education Commission (OHEC). 2011. Foreign students in Thai higher education in 2010. Bangkok: Office of the Higher Education Commission. . 2012. Study in Thailand 2012. http://inter.mua.go.th/main2/ article. php?id=301 (accessed 10 May 2015).

Ozturgut, O. and Murphy, C. 2009. Literature vs. practice: Challenges for international students in the U.S. International Journal of Teaching and Learning in Higher Education 2 (3): 374-385.

Pantelidou, S. and Craig, T. 2006. Culture shock and social support: A survey of Greek migrant students. Social Psychiatry and Psychiatric Epidemiology 41: 777-781, https://doi.org/10.1007/s00127-006-0096-5.

Phinney, J. 1990. Ethnic identity in adolescents and adults: Review of research. Psychological Bulletin 108: 499-514, https://doi.org/10.1037/0033-2909.108.3.499.

Poyrazli, S. and Grahame, K. M. 2007. Barriers to adjustment: Needs of international students within a semi-urban campus community. Journal of Instructional Psychology 34 (1): 28-45.

Ramachandra, N. 2011. Enhancing international students' experiences: An imperative agenda for universities in the UK. Journal of Research in International Education 10 (2): 201-220, https://doi.org/10.1177/1475240911413204.

Richards, G. and Wilson, J. 2003. Today's youth travellers: Tomorrow's global nomads. New horizons in independent youth and student travel. Amsterdam: International Student Travel Confederation (ISTC).

Rizvi, F. 2011. Theorizing student mobility in an era of globalization. Teachers \& Teaching 17 (6): 693-701, https://doi.org/10.1080/13540602.2011.625145.

Rosenthal, D., Russell, J. and Thomson, G. 2007. Social connectedness among international students at an Australian university. Social Indicators Research 84: 71-82, https:// doi.org/10.1007/s11205-006-9075-1.

Rujiprak, V. 2016. Cultural and psychological adjustment of international students in Thailand. International Journal of Behavioral Science 11 (2): 127-142.

Sawir, E. et al. 2008. Loneliness and international students: An Australian study. Journal of Studies in International Education 12: 148-180, https://doi. org/10.1177/1028315307299699. 
Searle, W. and Ward, C., 1990. The prediction of psychological and sociocultural adjustment during cross-cultural transitions. International Journal of Intercultural Relations 14: 449-464, https://doi.org/10.1016/0147-1767(90)90030-Z.

Seeber, M. et al. 2016. Why do higher education institutions internationalize? An investigation of the multilevel determinants of internationalization rationales. Higher Education: The International Journal of Higher Education Research 72 (5): 685-702, https://doi.org/10.1007/s10734-015-9971-x.

Stohl, M. 2007. We have met the enemy and he is us: The role of the faculty in the internationalization of higher education in the coming decade. Journal of Studies in International Education 11 (3/4): 359-372, https://doi. org/10.1177/1028315307303923.

Sumer, S., Poyrazli, S. and Grahame, K. 2008. Predictors of depression and anxiety among international students. Journal of Counselling and Development 86 (4): 429-437, https://doi.org/10.1002/j.1556-6678.2008.tb00531.x.

Swagler, M. and Ellis, M. 2003. Crossing the distance: Adjustment of Taiwanese graduate students in the United States. Journal of Counseling Psychology 50 (4): 420-437, https://doi.org/10.1037/0022-0167.50.4.420.

Swagler, M. and Jome, L. 2005. The effects of personality and acculturation on the adjustment of North American sojourners in Taiwan. Journal of Counseling Psychology 52 (4): 527-536, https://doi.org/10.1037/0022-0167.52.4.527.

Swami, V. et al. 2010. Sociocultural adjustment among sojourning Malaysian students in Britain: a replication and path analytic extension. Social Psychiatry and Psychiatric Epidemiology 45 (1): 57-65, https://doi.org/10.1007/s00127-009-0042-4.

Tajfel, H. and Turner, J. C. 1979. An integrative theory of intergroup conflict. In The social psychology of intergroup relations, ed. Austin, W. G. and Worchel, S, 33-47. Monterey: CA: Brooks.

Tidarat, R. 2002. The popularization of Japanese youth culture in the media in Thailand. MA diss., Chulalongkorn University, Thailand.

Thamdee, D. 2007. Continuity of Korean Studies in Thailand. RU International Journal 1 (1): 209-224.

Townsend, P. and Wan, C. 2007. The impact of multicultural experience in the development of sociocultural adaptation for international business students. International Journal of Educational Management 21 (3): 194-212, https://doi. org/10.1108/09513540710738656.

Townsend, P. and Poh, H. J. 2008. An exploratory study of international students studying and living in a regional area. Journal of Marketing for Higher Education 18 (2): 240-263.

Trice, A. 2003. Faculty perceptions of graduate international students: The benefits and challenges. Journal of Studies in International Education 7: 379-403, https://doi. org/10.1177/1028315303257120.

Torbiorn, I. 1994. Dynamics of cross-cultural adaptation. In Learning across cultures, ed. Althen, G. New York: NAFSA.

Toyokawa, T. and Toyokawa, N. 2002. Extracurricular activities and the adjustment of Asian international students: A study of Japanese students. International Journal of Intercultural Relations 26: 363-379, https://doi.org/10.1016/S01471767(02)00010-X. 
Ubonrat, S. and Shin, H. 2007. Asianizing K-pop: production, consumption and identification patterns among Thai youth. Inter-Asia Cultural Studies 8 (1): 109-136, https://doi. org/10.1080/14649370601119113.

Visser, D. 2002. What hip Asians want: A little bit of Seoul; From films to fashion, Korean pop culture becomes "Kim Chic" across Continent. Washington Post, 10 March. http://seattlepi.nwsource.com/national/56897_pac04.shtml (accessed 20 May 2015).

Wang, J. 2009. A study of resiliency characteristics in the adjustment of international graduate students at American universities. Journal of Studies in International Education 13 (1): 22-45, https://doi.org/10.1177/1028315307308139.

Ward, C. 1996. Acculturation. In Handbook of intercultural training, 2nd ed., ed. Landis, D. and Bhagat, R. S., 24-147. Thousand Oaks, CA: Sage Publications. 2004. Psychological theories of culture contact and their implications for intercultural training and interventions. In Handbook of intercultural training, 3rd ed., ed. Landis, D. Bennett, J. M. and Bennett, M. Thousand Oaks, CA: Sage, https://doi.org/10.4135/9781452231129.n8.

Ward, C., Bocher, S. and Furnham, A. 2001. The psychology of culture shock, 2nd ed. East Sussex: Routledge.

Ward, C. and Kennedy, A. 1999. The measurement of sociocultural adaptation. International Journal of Intercultural Relations 23 (4): 659-677, https://doi.org/10.1016/S01471767(99)00014-0.

Ward, C. and Searle, W. 1991. The impact of value discrepancies and cultural identity on psychological and sociocultural adjustment of sojourners. International Journal of Intercultural Relations 15: 209-224, https://doi.org/10.1016/01471767(91)90030-K.

WYSE. 2006. About us. http://www.aboutwysetc.org/AboutUs.aspx (accessed 14 May 2009).

Yeh, C. J. and Inose, M. 2003. International students' reported English fluency, social support satisfaction, and social connectedness as predictors of acculturative stress. Counseling Psychology Quarterly 16: 15-28, https://doi.org/10.1080/0951507031 000114058.

Yusoff, Y. M. 2011. International students' adjustment in higher education relation between social support, self efficacy, and sociocultural adjustment. Australian Journal of Business and Management Research 1: 1-15.

Yusoff, Y. M. and Chelliah, S. 2010. Adjustment in international students in Malaysian public university. International Journal of Innovation, Management and Technology, $1(3): 275-278$. 